\title{
DESIGN PROTECTION AND THE LEGISLATIVE AGENDA
}

\author{
J. H. REICHMAN* \\ I \\ INTRODUCTION
}

Design protection was one of the topics that engaged Chairman Robert W. Kastenmeier most strenuously during his long tenure as legislative overseer of intellectual property rights. As a Congressman who genuinely believed that the public interest was best served by free competition, ${ }^{1}$ he never fully persuaded himself that domestic design industries needed more protection than the design patent law already afforded. ${ }^{2}$ The same convictions led him to resist the drive to protect integrated circuit designs in literary and artistic property law, although that drive eventually produced the Semiconductor Chip Protection Act of $1984 .^{3}$ Unfortunately, the very design industries that were denied sui generis protection in $1976^{4}$ soon turned to federal unfair competition law for a substitute form of relief that has produced increasingly anti-competitive effects. ${ }^{5}$ Moreover, the decision to exempt one class of functional designs from the strict conditions of patent law in the

Copyright $(1992$ by J. H. Reichman

* Professor of Law, Vanderbilt University.

My thanks to the German Marshall Fund of the United States, the Kapor Family Foundation, the Vanderbilt University Research Council, and Dean John J. Costonis for funding the research on which this article is based.

1. See Robert W. Kastenmeier \& Michael J. Remington, The Semiconductor Chip Protection Act of 1984: A Swamp or Firm Ground?, 70 Minn L Rev 417, 438-42 (1985) ("At the outset, the proponents of change should have the burden of showing that a meritorious public purpose is served by the proposed congressional action."); see also Robert W. Kastenmeier \& David Beier, International Trade and Intellectual Property: Promise, Risks, and Reality, 22 Vand J Transnatl L 285, 305-07 (1989). The political tests used to evaluate whether the proponents of legal protection for any given subject matter have met their burden of proof were largely inspired by Professors David Lange and L. Ray Patterson. See Copyright and Technological Change, Hearings before the Subcommittee on Courts, Civil Liberties and the Administration of Justice of the House Committee on the Judiciary, 98th Cong, Ist Sess 57-58, 64-68 (1983) (statement of David Lange, Professor of Law, Duke University); L. Ray Patterson, Copyright in Historical Perspective 228-29 (Vanderbilt U Press, 1968).

2. For Chairman Kastenmeier's reluctance to depart from the design patent law, 35 USC $\$ \S 171-73$ (1988), see J. H. Reichman, Design Protection in Domestic and Foreign Copyright Law: From the Berne Revision of 1948 to the Copyright Act of 1976, 1983 Duke L J 1143, 1261-64; J. H. Reichman, Design Protection After the Copyright Act of 1976: A Comparative View of the Emerging Interim Models, $31 \mathrm{~J}$ Copyright Society of USA 267, 358-61 (1984).

3. 17 USC $\$ \S 901-14$ (1988); see Kastenmeier \& Remington, 70 Minn L Rev at 424-30 (cited in note 1 ).

4. For the congressional decision not to enact a sui generis design bill as part of the General Revision of Copyright Law in 1976, see generally Reichman, 1983 Duke LJ at 1186-1200, 1262 n644 (cited in note 2); see also notes $49-53$ and accompanying text.

5. See notes 53-66 and accompanying text. 
Semiconductor Chip Protection Act of $1984^{6}$ has elicited pressures both here and abroad for the protection of all functional designs on similarly relaxed conditions, pressures to which the British government acceded in 1988. ${ }^{7}$ The paradoxical result is that the only industrialized country never to afford appearance designs any sui generis protection at all-the United States-seems on the verge of enacting a sui generis law to protect functional designs of every kind $^{8}$ that would radically undermine the patent system and the free-market principles it sustains. ${ }^{9}$

This article, based on the findings of a recent monograph, ${ }^{10}$ was initially drafted in the hopes of enlisting Chairman Kastenmeier's aid in resolving this paradox. ${ }^{11}$ It seems fitting to publish it here, as an expression of my respect for his accomplishments and as a plea that his concern for the public interest will continue to inspire those responsible for intellectual property legislation.

\section{II}

\section{The Need for a Special Design Law}

The enactment of an appropriate design protection law is in the best interests of the United States. Historically, the opponents of such laws contend that because sound marketing strategy requires manufacturers to improve the appearance of their products, consumers would have to pay unjustifiably high prices if industrial designers routinely obtained exclusive proprietary rights. ${ }^{12}$ This same kind of argument was previously levelled against other forms of intellectual property protection, including patents and copyrights, by those who believe the market always solves its own problems. Today, however, economists have a clearer understanding of just how intellectual property laws tend to organize relatively efficient markets for

6. While the patent law denies eligibility to any discovery that fails to meet the requirements of novelty, nonobviousness and utility, 35 USC $\$$ 102-03 (1988), the copyright law requires only "original works of authorship," 17 USC $\$ 102$ (a) (1988), which signifies independent creation plus a modicum of creative authorship. See Feist Publications $v$ Rural Telephone Serv., Inc., 111 S Ct 1282 (1991); Paul Goldstein, 1 Copynght: Principles, Law and Practice $\$ 2.2$ (Little Brown, 1989). Eligibility under the Semiconductor Chip Protection Act of 1984 turns on a variant of "originality" that resembles the copyright standard. See 17 USC § 902(b) (1988); Jay Dratler, Jr., Intellectual Property Law: Commercial, Creative, and Industrial Property \& 8.03[3] (Law Journal Seminars Press, 1991).

7. Copyright, Designs and Patents Acts of 1988, $\$$ 213-64 (UK); see generally Christine Fellner, The New United Kingdom Industrial Design Law, 19 U Balt L Rev 369, 377-88 (1989/1990). For similar legislative proposals in the United States, see note 84 and accompanying text.

8. See notes $84-90$ and accompanying text.

9. See Bonito Boats, Inc. v Thunder Craft Boats, Inc., 489 US 141 (1989) (emphasizing relation between patent system and free competition for unpatented products); see also notes $90-98$ and accompanying text.

10. See generally J. H. Reichman, Design Protection and the New Technologies: The United States Experience in a Transnational Perspective, 19 U Balt L Rev 6 (1989/1990), abridged version reprinted in 1991 Indus Prop 220 and 1991 Indus Prop 257 (Part 1 and Part 2, respectively).

11. See Industrial Design Protection, Hearings before the Subcommittee on Courts, Intellectual Property, and the Administration of Justice of the House Committee on the Judiciary, 101 st Cong, 2d Sess 510-27 (1990) (statement and testimony of J. H. Reichman, Professor of Law, Vanderbilt University).

12. See, for example, Matthew Nimetz, Design Protection, 15 Copyright L Sympos (ASCAP) 79, 104-08 (1967). 
investment in intangible intellectual goods. ${ }^{13}$ Recent studies suggest that industrial design, like computer programs and other forms of applied scientific know-how, cannot yield long-term rewards to innovators if the shortterm profits from successful innovation are consistently appropriated by freeriders who do not share the costs and risks of the creative process. ${ }^{14}$

A lack of adequate legal protection for industrial designs penalizes those industries willing and able to strengthen their domestic and international competitiveness by risking substantial investment in design innovation. ${ }^{15}$ American industry is confronted with a discriminating and increasingly integrated world market in which the ability of all countries, including developing countries, to supply standardized industrial products at competitive prices is a new fact of economic life. If industrialized countries are to maintain their comparative advantages in this global market, they must continue to outdistance the newcomers in regard to both advanced technological innovation and the design of more conventional productsendeavors in which the industrialized countries possess deeper resources of skill, capital, and marketing expertise. ${ }^{16}$

It should be emphasized that the most innovative designs are usually developed by small- and medium-sized firms that make up for a lack of market power by exceeding slothful oligopolists in improving the appearance and functional efficiency of their products through new and costly engineering techniques. Because the fruits of this investment do not remain sealed behind factory walls, however, manufacturers cannot invoke state trade secret laws that protect other forms of unpatented, noncopyrightable innovation. ${ }^{17}$ On the contrary, industrial design concerns intangible products of skilled efforts that are embodied in useful articles and distributed on the open market. Such products bear their know-how on their faces: anyone who obtains possession of the tangible support can swiftly reproduce the intangible design know-how it embodies without having to incur even the costs of reverse engineering. ${ }^{18}$

13. See, for example, Michael Lehmann, Property and Intellectual Property: Property Rights as Restrictions on Competition in Furtherance of Competition, 20 IIC, Intl Rev of Indus Prop \& Copyright 1 (1989); Hanns Ullrich, The Importance of Industrial Property and Other Legal Measures in the Promotion of Technological Innovation, 28 Indus Prop 102 (1989); Edmund W. Kitch. The Nature and Function of the Patent System, $20 \mathrm{~J}$ L \& Econ 265 (1977). See also Wendy J. Gordon, An Inquiry into the Merits of Copyright: The Challenges of Consistency, Consent and Encouragement Theory, 41 Stan L Rev 1343 (1989).

14. See, for example, Ralph S. Brown, Design Protection: An Overview, 34 UCLA L Rev 1341, 1386-1404 (1987); William T. Fryer, III, Industrial Design Protection in the United States of America-Present Situation and Plans for Revision, 19 U Balt L Rev 198, 198-99, $219-20$ (1989/1990); see generally J. H. Reichman, Computer Programs As Applied Scientific Know-How: Implications of Copyright Protection for Commercialized University Research, 42 Vand L Rev 639, 648-68 (1989).

15. See, for example, Cooper C. Woodring, A Designer's View of Current Industrial Design Protection in the United States, 19 U Balt L Rev 154 (1989/1990); Thomas Lowy, Design Protection in Lamp Design and Manufacturing, 19 U Balt L Rev 160 (1989/1990).

16. See generally J. H. Reichman, Intellectual Property in International Trade: Opportunities and Risks of a GATT Connection, 22 Vand J Transnatl L 747, 754-61, 814-15 (1989); see also Marshall A. Leaffer, Protecting United States Intellectual Property Abroad: Toward a New Multilateralism, 76 Iowa L Rev 273, 275 (1991).

17. See, for example, Jay Dratler, Jr., Trade Secrets in the United States and Japan: A Comparison and Prognosis, 14 Yale J Intl L 68, 89-99 (1989); see also note 73.

18. See generally Reichman, 42 Vand L Rev at 654-62 (cited in note 14). 
Because free-riding competitors duplicate only those designs that have already captured the public's fancy and achieved commercial success, they have no losses from unsuccessful essays to recoup and no research and development costs to defray. Their ability to price imitated goods below the innovator's marginal costs enables free-riders to reduce the innovator's lead time to zero. ${ }^{19}$

Although consumers benefit from this unbridled price competition in the short run, the small- and medium-sized producers whose talents are their primary assets will be driven out of target markets over time by cut-throat competitors who never adequately fund the process of design innovation. ${ }^{20}$ Meanwhile, foreign producers, benefiting in part from better design laws, inundate our markets with well-designed products that first attract the most discriminating buyers and then capture large segments of the mass market whose constituents also want products that do more than satisfy bare human needs. ${ }^{21}$

Anyone who demands empirical evidence that poor design constitutes a serious handicap in today's world market has only to study the balance of trade statistics and the bearish message they harbor. ${ }^{22} \mathrm{~A}$ fair conclusion is that small- and medium-sized industry needs appropriate legal tools to fend off free-riders and also to oblige the larger industries to pay for the actual costs of the designs they often borrow. Given the proper incentives, the products of our design industries could compete more effectively with imported goods in vulnerable domestic markets, while there is every reason to expect these same industries to enhance our export potential as well. ${ }^{23}$

This said, let me briefly survey the design protection schemes already in place, with a view to understanding how they could be improved without triggering new diseconomies that might jeopardize the benefits of legislative reform.

\section{III}

\section{Present Status of Design Protection Law}

Turning to the legal status of industrial design in domestic law, my latest study shows that the United States already has more design protection than a casual observer might suppose and far more of the wrong kind of protection than is good for a competitive economy. The first reference is to the Design Patent Act of 1842,24 which the Court of Appeals for the Federal Circuit has

19. See generally Reichman, 19 U Balt L Rev at 136-44 (cited in note 10) (citing authorities).

20. See, for example, Lowy, $19 \mathrm{U}$ Balt $L \mathrm{Rev}$ at 160-61 (cited in note 15).

21. See generally Woodring, 19 U Balt L Rev at 154-59 (cited in note 15).

22. See D. O. Ughanwa \& M. J. Baker, The Role of Design in International Competitiveness 243, 243343 (Routledge, 1989); Christopher Lorenz, The Design Dimension-Product Strategy and the Challenge of Global Marketing 40-47 (Blackwell, 1986).

23. See note 15.

24. Act of Aug 29,1842 , ch $263, \S 2,5$ Stat 543 (1842), codified as amended at 35 USC $\S \S 171$ 73,289 (1988). 
revitalized in recent years. ${ }^{25}$ The second and more negative reference is to section $43(\mathrm{a})$ of the Lanham Act, ${ }^{26}$ which the federal appellate courts have converted into a judge-made design law during the past ten years. ${ }^{27}$

Recent improvements in design patent protection can be demonstrated statistically. Consider, for example, that prior to the 1980 s the federal appellate courts invalidated from 70 to 100 percent of all the issued design patents that reached them in the course of infringement actions. ${ }^{28}$ In contrast, of thirteen cases concerning ornamental designs of useful articles known to have reached the new Federal Circuit between the second quarter of 1986 and the first half of $1990,{ }^{29}$ only two invalidate designs for obviousness, both unpublished, ${ }^{30}$ and there is only one clear instance of invalidation for functionality. ${ }^{31}$ In this same period, patented designs were found both valid and infringed in two out of five cases that required the Federal Circuit to apply the refined infringement analysis it has taken pains to develop. ${ }^{32}$

25. See generally Reichman, $19 \mathrm{U}$ Balt $\mathrm{L} \mathrm{Rev}$ at 19-56 (cited in note 10). See also Perry J. Saidman, The Glass Slipper Approach to Protecting Industrial Designs or When the Shoe Fits, Wear It, 19 U Balt L Rev 167, 173-84 (1989/1990).

26. Lanham Act, ch $540, \S 43(a), 60$ Stat 427,441 (1946), codified as amended at 15 USC $\S 1125$ (a) (1988).

27. See generally Reichman, $19 \mathrm{U}$ Balt L Rev at 81-123 (cited in note 10); Brown, 34 UCLA L Rev at 1341, 1357-80 (cited in note 14); see also John B. Pegram, The Scope of Industrial Design Protection Under Trademark and Unfair Competition Laws, 19 U Balt L Rev 333 (1989/1990). But see Jay Dratler, Jr., Trademark Protection for Industrial Designs, 1988 U Ill L Rev 887 (1988) (approving the trend). In contrast, few modern three-dimensional designs obtain full copyright protection, in keeping with the separability requirement codified in section 101 of the Copyright Act of 1976,17 USC $\S 101$ (1988). That three-dimensional designs do not obtain full copyright protection follows because the Copyright Office and the courts are once again speaking a common language in regard to this requirement, while the split in the circuits opened in 1980 has largely healed of its own accord. See Dorothy Schrader, Copyright Office Registration of Industrial Designs, 19 U Balt L Rev 445 (1989/1990). Compare Kieselstein-Cord v Accessories by Pearl, Inc., 632 F2d 989 (2d Cir 1980), with Brandir Intl., Inc. v Cascade Pacific Lumber Co., 834 F2d 1142 (2d Cir 1987) and Esquire, Inc. $v$ Ringer, 591 F2d 796 (DC Cir 1978). See generally Reichman, 19 U Balt L Rev at 56-81 (cited in note 10); Robert C. Denicola, Applied Art and Industrial Design: A Suggested Approach to Copyright in Useful Articles, 67 Minn L Rev 707 (1983).

28. See, for example, Thomas B. Lindgren, The Sanctity of the Design Patent: Illusion or Reality? Twenty Years of Design Patent Litigation Since Compco Corp. v. Day-Brite Lighting, Inc., and Sears, Roebuck \& Co. v. Stiffel Co., 10 Okla City U L Rev 195, 207, 209 (1985); Reichman, 1983 Duke LJ at $1190 \mathrm{n} 245$ (cited in note 2) (citing authorities); see also Lawrence Baum, The Federal Courts and Patent Validity: An Analysis of the Record, $56 \mathrm{~J}$ Patent Office Society 758, 763 (1974).

29. See Reichman, $19 \mathrm{U}$ Balt L Rev at 54-55 (cited in note 10) (citing authorities).

30. Neo-Art, Inc. v Hawkeye Distilled Prods. Co., 12 USPQ2d (BNA) 1572 (Fed Cir 1989); John Thomas Batts, Inc. $v$ S.O. Textiles Co., No 88-1 134 (Fed Cir, Nov 17, 1988). Published recent decisions do not deviate from this trend.

31. Power Controls Corp. v Hybrinetics, Inc., 806 F2d 234, 238-40 (Fed Cir 1986). See also Eldon Indus., Inc. v Vanier Mfg., Inc., 923 F2d 869 (Fed Cir 1990).

32. Compare Avia Group Intl v L.A. Gear Cal., 853 F2d 1557 (Fed Cir 1988) (holding designs for shoe sole and upper part valid and infringed) and Pacific Fumiture Mfg. Co. v Preview Fumiture Corp., 800 F2d 1111 (Fed Cir 1986) (holding design of upholstered armchair valid and infringed) with $F M C$ Corp. $v$ Hennessy Indus., Inc., 836 F2d 501 (Fed Cir 1987) (affirming lower court finding that design of single-power-source tire changer was valid but not infringed in action for declaratory judgment by alleged infringer) and Lee $v$ Dayton-Hudson Corp., 838 F2d 1186 (Fed Cir 1988) (holding design for massage implement valid but not infringed) and Winner Intl. Corp. $v$ Wolo Mfg. Corp., 905 F2d 375 (Fed Cir 1990) (vacating finding of invalidity and holding design of anti-theft bar-type steering wheel lock not infringed under point of novelty test); see also Independent Prods. Co. $v$ Tamor Plastics Corp., 930 F2d 
Even when cases from the Court's early, transitional phase and from the later, more mature phase are combined, the results are hardly less astonishing. Of twenty-two relevant cases known to have reached the Court of Appeals for the Federal Circuit between 1982 and the first half of 1990, there were only two instances of invalidation for functionality. ${ }^{33}$ Of eighteen cases in which the inventive height was directly or indirectly challenged, there were only three instances of invalidation for obviousness. ${ }^{34}$ Of ten relevant cases known to have reached the decisive phase of an infringement action between 1983 and the first half of 1990 , four concerned patented designs that were ultimately found valid and infringed..$^{35}$

These findings do not mean that the United States already possesses an efficient, modern design law. For example, the design patent law still requires a full examination of the prior art, which makes it too costly, slow and cumbersome for the bulk of the commercial designs competing in today's fastpaced consumer markets. Moreover, the statutory requirement of nonobviousness by definition excludes all but the most exceptionally creative designs, and it affords little or no protection to the kind of incremental innovation that is characteristic of the design industries as a whole. ${ }^{36}$

Nevertheless, most of the sui generis design laws operating in the European Community countries are only marginally better. For example, foreign laws (with some exceptions) tend to allow designers no novelty grace period in which to test-market their output. Hence, those laws invalidate far more designs for lack of novelty than does the United States patent law, ${ }^{37}$ whose one-year grace period benefits designs in commerce. ${ }^{38}$ Moreover, the requirements of registration and deposit under foreign law, though less onerous than in the United States, remain too costly and burdensome for

38 (Fed Cir 1991) (plastic hanger design valid and infringed). See generally Reichman, 19 U Balt L Rev at 51-53, 55 (cited in note 10); Saidman, 19 U Balt L Rev at 174-80 (cited in note 25).

33. The two cases are Power Controls, 806 F2d 234, and Feuling $v$ Wood, Nos 84-543, 84-662 (Fed Cir, Nov 30, 1984). See also Chrysler Motors Corp. v Auto Body Parts of Ohio, Inc., 908 F2d 951 (Fed Cir 1990).

34. The three cases are Petersen Mfg. Co. $v$ Central Purchasing, Inc., 740 F2d 1541 (Fed Cir 1984); Neo-Art, Inc. v Hawkeye Distilled Prods Co., 12 USPQ2d (BNA) 1572 (Fed Cir 1989); and John Thomas Batts, Inc. v S.O. Textiles Co., No 88-1134 (Fed Cir, Nov 17, 1988).

35. Compare Avia, 853 F2d 1557 and Pacific Furniture, 800 F2d 1111 and Trans-World Mfg. Corp. v Al Nyman छ Sons, Inc., 750 F2d 1552 (Fed Cir 1984) and Fiberglass in Motion, Inc. v Hindelang, No 831266 (Fed Cir, April 19, 1984) (all upholding design patents valid and infringed) with Winner, 905 F2d 375 and Lee, 838 F2d 1186 and FMC, 836 F2d 501 and Unette Corp. $v$ Unit Pack Co., 785 F2d 1026 (Fed Cir 1986) and Litton Sys., Inc. $v$ Whirlpool Corp., 728 F2d 1423 (Fed Cir 1984) and Shelcore, Inc. v Durham Indus., Inc., 745 F2d 621 (Fed Cir 1984) (all holding design patents valid but not infringed). See also Tamor Plastics Corp., 930 F2d 38 (valid and infringed). The United States thus clearly meets its obligations to protect industrial designs under article 5quinquies of the Paris Convention for the Protection of Industrial Property (1883). Whether the lack of a sui generis design law is consistent with this country's obligations under the Berne Convention for the Protection of Literary and Artistic Property (1886), as revised in 1948, poses a closer and more controversial question. See Reichman, 19 U Balt L Rev at 25-26 n109 (cited in note 10); Reichman, 1983 Duke L J at 1149-67 (cited in note 2). 10).

36. 35 USC $\S \S 103,171$ (1988); see generally Reichman, 19 U Balt L Rev at 46-54 (cited in note

37. Reichman, 19 U Balt $L$ Rev at $\mathbf{2 0 - 2 4}$ (cited in note 10) (citing authorities).

38. 35 USC $\S \S 102,171$ (1988). 
most foreign designers to make routine use of these laws. Finally, both the qualitative originality standard and, with some notable exceptions, the functionality standard that most foreign design laws impose in one form or another tend to exclude the bulk of the designs they are nominally supposed to protect. $^{39}$

On both sides of the Atlantic, one discerns a recurring, cyclical pattern that swings from states of chronic underprotection to states of chronic overprotection and then back to underprotection once again. An initial condition of underprotection stems from the assimilation of ornamental designs to the full patent paradigm, as still occurs in the United States and in a few other industrialized countries. Because very few designs ever satisfy the substantive and procedural requirements of a developed patent system, proponents of reform often stress the artistic nature of industrial design in order to justify protection under the mature copyright paradigm of the Berne Union countries. The cyclical pattern this strategy triggers can be summarized as follows:

Traditionally, the right to copyright protection is premised on a claim that certain
industrial designs are entitled to legal recognition as art in the historical sense. The
[adverse] economic repercussions of such recognition flow principally from the
industrial character of the material support in which ornamental designs are
embodied. The incidence of these repercussions upon any given system varies with
the extent to which the claim to recognition as art is itself given effect. As copyright
protection for designs of useful articles expands, the ... [anticompetitive] effects of
this expansion on the general products market induce countervailing pressures to
reduce the scope of protection acquired in the name of art. As protection in copyright
law correspondingly contracts, pressure for recognition of industrial art as a legally
protectible form of industrial property normally increases. The tendency of industrial
property law to breed still further instances of underprotection [that is, in sui generis
laws built on modified patent principles] or overprotection [that is, in unfair
competition laws sounding in the misappropriation rationale] then fosters renewed
pressures for the regulation of industrial art within the framework of the laws
governing literary and artistic property. ${ }^{40}$

In other words, chronic underprotection in industrial property law leads to chronic overprotection in artistic property law, which in turn inspires further reactive reforms of industrial property law tending to reinstate levels of underprotection that will foster renewed appeals to copyright law.

It may be helpful to illustrate this cyclical pattern by reference to certain lamp designs that have figured prominently in domestic law. Consider, for example, the famous lamps in the shape of Bali dancers that entered United States copyright law when the Supreme Court decided Mazer $v$. Stein ${ }^{41}$ in 1954. These lamps established the category of applied art in United States copyright law at a time when the design patent law gave no effective protection and the Universal Copyright Convention required some minimal recognition of this subject matter. To avoid overprotecting industrial art in

39. See Reichman, 19 U Balt L Rev at 20-24 (cited in note 10) (citing authorities).

40. Reichman, 1983 Duke $\mathrm{LJ}$ at 1143 (cited in note 2). See also Reichman, 19 U Balt L Rev at 126-35 (cited in note 10).

41. 347 US 201 (1954). 
copyright law, however, the Copyright Office Regulations introduced a neoItalian criterion of separability in 1958, which sought to confine modern three-dimensional designs of useful articles to the design patent law or to any sui generis design law that might replace it. ${ }^{42}$

In response, the design industries turned to state unfair competition laws for protection against slavish imitation, as evidenced by the Stiffel pole lamp and the Day-Brite fluorescent lamp that figured in the Sears-Compco cases of 1964. ${ }^{43}$ Had the lower courts' decisions stood, they would have ushered in a new period of overprotection rooted in the misappropriation rationale of International News Service v. Associated Press. ${ }^{44}$ But the Supreme Court's rejection of this rationale in Sears-Compco appeared to forbid state courts (and possibly federal courts, too) from protecting unpatented, noncopyrightable designs of useful articles against copying as such. ${ }^{45}$ As a result, another period of underprotection seemed inevitable unless Congress enacted an appropriate sui generis design law.

Between 1964 and 1976, designers turned back to copyright law for occasional relief and increasingly challenged the Register's restrictive interpretation of Mazer $v$. Stein, which had never received legislative endorsement. In the 1970s, some United States courts began to allow certain three-dimensional designs of useful articles to enter copyright law, notwithstanding the separability criterion embodied in the regulations. ${ }^{46}$ This movement culminated in early 1976, when a federal district court admitted Esquire's outdoor parking lamp to copyright law because it was ornamental by day and useful by night. ${ }^{47}$ Suddenly, the exorbitant protection of industrial designs in copyright law that still occurs under the French system $^{48}$ seemed an acquired fact of United States intellectual property law.

Of course, Congress repudiated this decision later in 1976 by codifying the criterion of separability in section 101 of the Copyright Act. ${ }^{49}$ In 1978, the District of Columbia Circuit retroactively invalidated the copyright in

42. See Reichman, 1983 Duke $\mathrm{L} J$ at $1181-88$ (cited in note 2) (citing authorities) (discussing origins of the separability doctrine in Italian law and its deliberate adoption by U.S. copyright authorities); see also Reichman, $19 \mathrm{U}$ Balt L Rev at 65-69 (cited in note 10) (recent refinement of domestic separability criterion in line with Italian law).

43. Sears, Roebuck E' Co. $v$ Stiffel Co., 376 US 225 (1964); Compco Corp. v Day-Brite Lighting, Inc., 376 US 234 (1964).

44. 248 US 215, 239 (1918). For an insightful reevaluation of this opinion, see Leo J. Raskind, The Misappropriation Doctrine as a Competitive Norm of Intellectual Property Law, 75 Minn L Rev 875 (1991).

45. See generally Brown, 34 UCLA L Rev at 1359-60, 1383-86 (cited in note 14). The SearsCompco decisions were partially codified at 17 USC $\$ 301$ (1988). See, for example, Goldstein, 2 Copyright at $\$ \S 15.2,15.3$ (cited in note 6); Howard B. Abrams, Copyright, Misappropriation, and Premption: Constitutional and Statutory Limits of State Law Protection, 1983 S Ct Rev 509.

46. See generally Reichman, 1983 Duke L J at 1238-49 (cited in note 2).

47. Esquire, Inc. v Ringer, 414 F Supp 939, 941 (D DC 1976), rev'd, 591 F2d 796 (DC Cir 1978); see note 27 .

48. See generally Yves Gaubiac, La théorie de l'unité de l'art, 111 RIDA, Revue Intl Droit D'Auteur 2 (1982).

49. 17 USC $\S 101$ (1988) (definitions of “pictorial, graphic and sculptural works" and "useful articles"); see note 27. 
Esquire's lamp design on the strength of this provision. ${ }^{50}$ But Congress did not enact a sui generis design law in 1976,51 while the Sears-Compco decisions of 1964 continued to bar state unfair competition laws from treating slavish imitation as a discrete business tort. ${ }^{52}$ In principle, designers had nowhere to turn once again, and another round of chronic underprotection seemed likely to ensue.

In reality, the federal appellate courts soon began to transform section 43(a) of the Lanham Act into a judge-made design law that afforded product configurations indefinite protection as unregistered appearance trade dress. ${ }^{53}$ Between 1985 and 1991, the designs of such highly utilitarian objects as luggage and handbags, ${ }^{54}$ plastic stacking trays, ${ }^{55}$ beverage servers, ${ }^{56}$ folding picnic tables, ${ }^{57}$ fishing reels, ${ }^{58}$ and industrial clamps ${ }^{59}$ all received de facto protection against copying on this approach. ${ }^{60}$

The full irony of this latest swing of the pendulum appears from two decisions, handed down in 1987 and 1989, concerning modern designs of halogen desk lamps developed in Italy. ${ }^{61}$ Under the legislation currently in force, neither the "Tizio" nor the "Dove" lamps qualified for hard protection on hard conditions for a period of fourteen years in design patent law, nor could they have obtained soft protection on soft conditions for a period of seventy-five to one hundred years in literary and artistic property law. ${ }^{62} \mathrm{~A}$

50. Ringer, 591 F2d 796. See also Norris Indus., Inc. v ITT Corp., 696 F2d 918 (11th Cir 1983) (holding designs of wire-spoked automobile wheel covers not copyrightable because functional and artistic components were inseparable). See generally Schrader, 19 U Balt L Rev at 445 (cited in note 27). For the Second Circuit's reluctant acceptance of the Copyright Office's revised regulations, see Brandir Intl, Inc. v Cascade Pacific Lumber Co., 834 F2d 1142 (2d Cir. 1987); note 27.

51. See note 4 and accompanying text.

52. See notes 43-45 and accompanying text.

53. See, for example, Warner Brothers, Inc. v Gay Toys, Inc., 658 F2d 76 (2d Cir 1981); Fabrica, Inc. $v$ El Dorado Corp., 697 F2d 890, 892-95 (9th Cir 1983); Truck Equip. Servs. Co. v Fruehauf Corp., 536 F2d 1210 (8th Cir 1976). See also Note, The Problem of Functional Features: Trade Dress Infringement Under Section 43(a) of the Lanham Act, 82 Colum L Rev 77 (1982) (authored by Jessica Litman).

54. Le Sportsac, Inc. v K Mart Corp., 754 F2d 71 (2d Cir 1985); see also Vuitton et Fils S.A. v J. Young Enters., Inc., 644 F2d 769 (9th Cir 1981). But see Coach Leatherware Co. VAnnTaylor, Inc., 933 F2d 162, 168-72 (2d Cir 1991).

55. W.T. Rogers Co. $v$ Keene, 778 F2d 334 (7th Cir 1985).

56. Service Ideas, Inc. v Traex Corp., 846 F2d 1118 (7th Cir 1988).

57. Vaughan Mfg. Co. v Brikam Intl. Inc., 814 F2d 346 (7th Cir 1987).

58. Brunswick Corp. v Spinit Reel Co., 832 F2d 513 (10th Cir 1987). See also Esercizio v Roberts, 944 F2d 1235 (6th Cir 1991) (automobile design).

59. Clamp Mfg. Co. v Enco Mfg. Co., 870 F2d 512 (9th Cir 1989).

60. See generally Reichman, $19 \mathrm{U}$ Balt L Rev at 86-121 (cited in note 10), and Brown, 34 UCLA L Rev at 1357-86 (cited in note 14) (both criticizing this trend); Dratler, $1988 \mathrm{U}$ Ill L Rev 887 (cited in note 27) (approving this trend).

61. See Artemide S.P.A. v Grandlite Design and Mfg. Co., 672 F Supp 698 (SDNY 1987) ("Tizio" design of halogen desk lamp entitled to preliminary injunction against copying as appearance trade dress); PAF S.r.l. v Lisa Lighting Co., 712 F Supp 394 (SDNY 1989) ("Dove" design of halogen desk lamp protected against copying as appearance trade dress that had acquired secondary meaning and was not functional). See also Bauer Lamp Co. v Shaffer, 941 F2d 1165 (1 1 th Cir 1991) (Neoclassic lamp designs were protected trade dress). For the revealing background to the "Dove" lamp case, which also shows the different kinds of benefits that accrue to the U.S. market from local investment even in foreign designs, see Lowy, 19 U Balt L Rev 160 (cited in note 15).

62. See note 6 (differentiating strict prerequisites of eligibility in patent law from the requirement of mere independent creation in copyright law) and notes $27 \& 50$ (effects of 
federal district court nonetheless protected both high-tech designs against copying for an indefinite period of time as nonfunctional appearance trade dress under section 43(a) of the Lanham Act. ${ }^{63}$ By 1989, in short, lamp designs like those denied copyright protection in 1976 routinely obtained more than copyright law had to offer under federal unfair competition law, even though Congress had refused to grant similar designs even ten years of protection on modified copyright principles in $1976 !^{64}$

Whether these excesses will survive the Supreme Court's recent decision in Bonito Boats, Inc. v. Thunder Craft Boats, Inc. ${ }^{65}$ remains to be seen. By reinvigorating Sears-Compco and reinstating the primacy of statutory intellectual property laws, this decision may restrain the federal appellate courts from covertly treating slavish imitation of product designs as a business tort for the immediate future.66 If so, however, an incipient period of overprotection in federal unfair competition law will simply give way to another period of chronic underprotection in design patent law unless Congress takes this occasion to enact a sui generis design law.

\section{IV}

\section{Regulating a Disruptive Legal Hybrid}

The American experience sketched above is strikingly similar to that of the other industrialized countries, and this resemblance is all the more remarkable when viewed in relation to the much longer period in which these countries have struggled with the issues that design piracy continues to

separability criterion on works of applied art). An issued patent forbids even independent creation by unauthorized third parties, 35 USC $\S 271$ (a) (1988), whereas copyright law prohibits only copying but not independent creation. See 17 USC $\$ \S 102(a), 501$ (1988); Goldstein, 2 Copyright at $\S 7.2 .1$ (cited in note 6).

63. PAF S.r.l., 712 F Supp at 394; Artemide S.P.A., 672 F Supp at 698. See also Bauer Lamp Co., 941 F2d 1165; Brandir, 834 F2d at 1148 (suggesting that lower court should protect noncopyrightable design of bicycle rack as appearance trade dress). But see Wallace Intl. Silversmiths, Inc. v Godinger Silver Art Co., 916 F2d 76 (2d Cir 1990) (rehabilitating modified doctrine of aesthetic functionality); Coach Leatherware Co., 933 F2d 162.

64. See note 4 and accompanying text.

65. 489 US 141 (1989) (holding state laws forbidding unauthorized reproduction of product configurations by direct molding process unconstitutional under Sears-Compco). See generally John Shepard Wiley, Jr., Bonito Boats: Uninformed But Mandatory Innovation Policy, 1989 S Ct Rev 283.

66. See Bonito Boats, 489 US at 157, 159-68 (declaring that the legitimate concern of unfair competition law lay in "protecting consumers from confusion as to source ... not [in] the protection of producers as an incentive to product innovation" and reaffirming the anti-protectionist mandate of Sears-Compco with particular reference to industrial designs). Compare Feist Publications $v$ Rural Telephone Service Co., 111 S Ct 1282, 1294 (1991) (rejecting sweat-of-the-brow theory of eligibility for copyright protection). See also Cicena Ltd. $v$ Columbia Telecommunications Group, 900 F2d 1546, 1553 (Fed Cir 1990) (rejecting misappropriation principle in the absence of strong secondary meaning in novel telephone design); Schwinn Bicycle Co. v Ross Bicycles, Inc., 870 F2d 1178 (7th Cir 1989) (rejecting misappropriation principles and reinstating modified aesthetic functionality test); Wallace Silversmiths, 916 F2d 76 (reviving modified aesthetic functionality test); Laureyssens v Idea Group, Inc., Nos. 917869, $91-7917$ (2d Cir, May 15, 1992) (rejecting doctrine of secondary meaning in the making); Taco Cabana Intl, Inc. v Two Pesos, Inc., 932 F2d 1113 (5th Cir. 1991) (distinctive restaurant decor was protected trade dress), cert granted, $112 \mathrm{~S}$ Ct 964 (1992). 
raise. ${ }^{67}$ Comparative analysis further shows that foreign legislative initiatives have failed to break the cyclical pattern illustrated above because sui generis design laws are almost invariably built on modified patent principles. ${ }^{68}$ The modified patent approach merely institutionalizes a state of chronic underprotection, while softening to some degree the procedural and substantive prerequisites of the full patent law paradigm.

Innovative industrial design typically concerns variations on known style trends that seldom take major strides beyond the prior art. ${ }^{69}$ The designer's know-how consists in giving physical expression to technical, organizational, and marketing demands, and in harmonizing these demands with aesthetic features in products that appeal to the world market. ${ }^{70}$ Increasingly, this know-how includes the use of laser holograms, computer-generated displays, and other new techniques, as well as the psychological and sociological inputs of human factors engineering. ${ }^{71}$

A patent approach normally excludes most incremental innovation by definition. ${ }^{72}$ Because even the most innovative product bears its design knowhow on its face, risk takers have little or no possibility of invoking the trade secret laws that otherwise protect unpatented innovation. ${ }^{73}$ In this respect, the design industries do resemble publishers of literary and artistic works who lack autonomous means of appropriating the fruits of high-risk investment in creations that attain commercial success. ${ }^{74}$ Publishers of literary and artistic

67. See, for example, Reichman, 1983 Duke L J at 1153-58 (cited in note 2) (case of France); id at 1182-86, $1213-23$ (case of Italy); Reichman, $31 \mathrm{~J}$ Copyright Society of USA at 283-97 (cited in note 2) (case of Benelux); id at 336-41 (case of Germany).

68. See generally Reichman, $19 \mathrm{U}$ Balt $\mathrm{L} \mathrm{Rev}$ at 14-15, 20-25, 133-35 (cited in note 10).

69. See, for example, Dratler, $118 \mathrm{U}$ Ill $\mathrm{L} \mathrm{Rev}$ at 892 (cited in note 27) (citing and quoting authorities); Wim Crouwel, A Designer's View of Plagiarism, in Herman Cohen Jehoram, ed, Design Protection 155, 161-62 (Sijthoff, Leyden, 1976).

70. See, for example, Ezio Manzini, The Material of Invention 53-54 (MIT Press, 1989); Lorenz, The Design Dimension at 10-27, 145-49 (cited in note 22); Robin Roy, Product Design and Innovation in a Mature Consumer Industry in Richard Langdon, ed, 2 Design Policy: Design and Industry 91 -97 (Design Council, 1984). As to the role of aesthetics, Professor Truijen states: "Now how must we view artistry in industrial design? The structure, composition, functioning and expression of an industrial utility product we call its appearance ... . [N]ow the designer harmonizes these . . divergent elements. Practicing design and even applied science in this creative manner is what I call artistry of the highest rank." E. A. H. Truijen, Industrial Design and the Design Law, in Cohen Jehoram, ed, Design Protection at 169, 170-71 (cited in note 69) (emphasis added).

71. See, for example, Ian Morris \& Barry Quest, Design-The Modern Law and Practice 184-89 (London, 1987); Ughanwa \& Baker, The Role of Design at 277-95 (cited in note 22); Katherine McCoy, Foreword, in Patrick Whitney, ed, 2 Design in the Information Environment: How Computing Is Changing the Problems, Processes and Theories of Design 5 (Southern Illinois U Press, 1985). See also Stanley Moody, The Role of Industrial Design in the Development of New Science-Based Products, in Langdon, ed, 2 Design Policy at 70, 73 (cited in note 70); Bill Curtis, Engineering Computer "Look and Feel": User Interface Technology and Human Factors Engineering, 30 Jurimetrics J 51, $63-76$ (1989).

72. See, for example, 17 USC $\S \S 103,171$ (1988); Avia, 853 F2d at 1563-65.

73. A trade secret remains protectible only so long as actual secrecy is preserved by reasonable means and it has not been reverse engineered by improper means. See Uniform Trade Secrets Act (with 1985 Amendments), 14 ULA 265 (1991); notes 17-19 and accompanying text. Compare, Elmer Galbi, Proposal for New Legislation to Protect Computer Programming, 17 Bulletin Copyright Society USA 280,281 (1970) (problem of know-how not protectible as trade secret).

74. Neither industrial designers nor publishers of literary and artistic works can resort to trade secret laws for the purpose of retaining a hold on their know-how or on products of skilled efforts in which it is embodied. See notes 17-21, 73 and accompanying text. 
works look to the mature copyright paradigm of the Berne Union countries, whose pliant modalities of protection serve to establish a better balance between private and public interests than would occur under purely competitive conditions. By the same token, the design industries whose products behave like literary and artistic works in the open market have repeatedly sought relief from copyright laws because the structural modalities of the copyright paradigm provide a coherent legal response to a common economic predicament. ${ }^{75}$

These observations do not mean that industrial designers should obtain all the benefits of the mature copyright paradigm; the opposite is true. Application of copyright law to industries that systematically exploit innovative know-how imposes intolerable restraints on trade and soon tends to stifle the very incremental innovation that prompted the demand for copyright protection in the first place. ${ }^{76}$ Moreover, broad application of copyright law to useful articles gradually subverts the capacity of the patent law to regulate competition on the general products market. This follows because the appearance designs of useful articles, which typically begin life as two-dimensional graphic works like any other commercial paintings, end by driving the markets for such products as automobiles, refrigerators, and dental equipment. ${ }^{77}$

The foregoing analysis does suggest that the legal protection of industrial designs (and of important new technologies as well) would greatly benefit from a judicious adaptation of copyright law that does not unduly disrupt the workings of a competitive market for industrial products. The task, in short, is to provide innovative design industries with a minimum period of artificial lead time in which to recoup their investment, without succumbing to the philosophical mystique of intellectual property laws that keep fair followers from entering the market. ${ }^{78}$

A similar principle was first enunciated by the high-level group of American experts responsible for drafting the Willis Bill of 1957, which later became the O'Mahoney-Wiley-Hart Bill of 1959 , known as S.2075. ${ }^{79}$ The innovative sui generis design law set out in these bills was heralded by Register Arthur Fisher as "a model to the rest of the world" precisely because it proposed a modified copyright approach to the protection of appearance

75. See generally Reichman, $19 \mathrm{U}$ Balt L Rev at 141-44 (cited in note 10).

76. See Reichman, 42 Vand L Rev at 671-700 (cited in note 14). For the negative experience of the United Kingdom in this respect, see Fellner, $19 \mathrm{U}$ Balt L Rev at 369 (cited in note 7).

77. See Reichman, 19 U Balt L Rev at 130-32 (cited in note 10). It is this capacity of appearance designs to compete in both the market for artistic works (as works of applied art) and in the general products market that aggravates the design problem. No facile invocation of general principles of copyright law will make this two-market conundrum disappear.

78. Id at 144. See further J. H. Reichman, Legal Hybrids Between the Patent and Copyright Paradigms (paper presented to the Forum on Intellectual Property Issues in Software, sponsored by the Computer Science and Technology Board, National Research Council, National Academy of Sciences, Washington, D.C., Sept 1989, and to the Conference on Information Law in the TwentyFirst Century, Institute for Information Law, University of Amsterdam, The Netherlands, June 1991 ).

79. See, for example, Industrial Design Protection at 435, 447-50 (cited in note 11 ) (statement of Ralph Oman, Register of Copyrights). 
designs in place of the modified patent approach prevalent in foreign law. ${ }^{80}$ The latest and most refined variant on this theme was launched by the Max Planck Institute in $1990,{ }^{81}$ and it has attracted support from the Commission of the European Communities. ${ }^{82}$

The modified copyright principles of S.2075 still constitute an interesting approach to the unsolved design puzzle, even though further refinements have become desirable in the light of past experience. ${ }^{83}$ From this angle, the virtue of the latest design bills pending before Congress is that, in one form or another, they would all institute a modified copyright approach. ${ }^{84}$ However, their biggest drawback is that they would expand the subject matter of protection to cover functional designs of every kind, including, for example, many automobile and tractor spare parts, while maintaining the soft substantive and formal prerequisites heretofore thought appropriate for purely decorative design features that appeal to the eye. ${ }^{85}$

\section{V}

\section{InCREMENTAL InNOVATION BEARING KNOW-How on Its FaCE}

The protection of functional designs under a low creativity standard, as proposed in these bills, ${ }^{86}$ would depart radically from general principles of

80. For a detailed analysis of these bills, see generally Reichman, 1983 Duke L J at 1186-1200 (cited in note 2).

81. See Towards a European Design Law (Max Planck Institute for Foreign and International Patent, Copyright and Competition Law, Munich, Germany, 1991). The American design bills of the period 1955-1976 provided a six-month novelty grace period and a ten-year term of protection; they also allowed alternative protection under the design patent law, which was not slated for repeal. See notes 79-80. The Max Planck Institute's draft law allows a choice between formal protection of up to 25 years by registration or informal protection against slavish imitation for a two-year period without registration.

82. See Commission of the European Communities, Green Paper on the Legal Protection of Industrial Design, Doc No $111 / \mathrm{F} / 5131 / 91-\mathrm{EN}$ at 52-53 (1991).

83. See, for example, Industrial Design Protection at 480-91 (cited in note 11) (statement of Ralph Oman, Register of Copyrights); Reichman, $19 \mathrm{U}$ Balt L Rev at 145-47 (cited in note 10); see also notes 78-82.

84. See Industrial Design Protection at 2-77 (cited in note 11) (texts of HR 902, HR 3017, HR 3499 as submitted to the 100th Congress); id at 435 (statement of Register Oman) (acknowledging the need for sui generis protection of ornamental designs that "would establish limited monopoly rights against copying," as provided in these bills, but criticizing them for allowing protection of functional rather than ornamental designs of useful articles). For the current version of these same proposals, see Design Innovation and Technology Act of 1991, HR 1790, 102d Cong, 1st Sess (April $16,1991)$.

85. See notes 79, 84; Industrial Design Protection at 480-85, 487-88 (cited in note 11 ); Ralph S. Brown, Copyright-Like Protection for Designs, $19 \mathrm{U}$ Balt L Rev 308, 314-23 (1989/1990). The latest proposal, HR 1790 (cited in note 84), maintains this modified copyright approach, although its sponsors are reportedly willing to exclude after-market repair parts affecting the internal performance of passenger cars and light-duty trucks.

86. The pending bills propose a general originality standard in the sense of independent creation, and they exclude staple or commonplace designs as well as designs that have become industry standards. However, any design derived from a staple, commonplace, or standard design that introduces a significant variation would be allowed, unless it was "dictated solely by a utilitarian function of the article that embodies it." See, for example, Industrial Design Protection at 3-5 (cited in note 11) (statement of Oman on HR 902, $\$ \$ 1001,1003$ ); id at 485-87 (criticizing these provisions for lack of clarity); Design Innovation and Technology Act, HR $1790 \S 1002$ (cited in note 84). 
world intellectual property law. ${ }^{87}$ In the past, countries willing to protect unpatented functional designs enacted utility model laws requiring standards of inventive activity that were only moderately less exigent than the nonobviousness standard of patent law.88 Countries that protect utility models, including Italy, Japan, Germany, and a growing number of developing countries, seek to encourage small-scale innovation that is particularly suited to local conditions. These laws nonetheless require evidence of a significant inventive contribution ${ }^{89}$ because the external configuration of virtually every utilitarian product affects its functional efficiency or performance. Unless competitors remained free to imitate the bulk of routine functional designs, utility model laws would convert design protection into a formula for diffuse monopolization of the general products market. Proposals to protect functional designs on much softer standards than those of utility model laws or, indeed, in return for no significant quantum of creative achievement whatsoever, constitute an unprecedented assault on the free market principles that underlie both domestic and international trade. ${ }^{90}$

Moreover, such proposals complicate an already difficult subject by casting fresh doubts on what exactly the sponsors of these legislative initiatives are trying to accomplish and why. If their object is to protect all innovative shapes or forms that have an industrial application, it begs the question as to why this type of innovation, but not others, should escape the price-setting function of the marketplace. If their concern is to encourage investment in innovation that remains particularly vulnerable to appropriation by freeriders, one wonders why other forms of incremental innovation that are at least as socially beneficial as functional designs should not be rescued from a

87. Nevertheless, such a radical departure was codified in the unregistered design right adopted by the United Kingdom in 1988. See note 7. It should be remembered, however, that between 1975 and 1988, only the United Kingdom routinely protected functional designs in copyright law owing to a legislative miscue in 1968 and to the penchant of that country's judiciary to use copyright law as a roving unfair competition law. See note 76 and accompanying text. The unregistered design right of 1988 thus signified a deliberate government attempt to cut back on the exorbitant protection of industrial designs during the previous decade. See generally Fellner, 19 U Balt L Rev 369 (cited in note 7 ).

88. See, for example, Stephen P. Ladas, 2 Patents, Trademarks, and Related Rights-National and International Protection 949-56 (Harvard U Press, 1975); Teruo Doi, The Intellectual Property Law of Japan 68-70 (Sijthoff \& Noordhaff, 1980); E. Häusser, Utility Models: The Experience of the Federal Republic of Germany, 26 Indus Prop 314 (1987); Reichman, 1983 Duke L J at 1217-21 (cited in note 2) (reviewing Italian utility model law and citing authorities). However, adoption of the Semiconductor Chip Protection Act of 1984 in the United States, see note 3 and accompanying text, introduced legal protection of one class of functional designs under soft prerequisites, like those of copyright law, rather than under hard prerequisites, like those of patent law. See note 6 .

89. See authorities cited in note 88. For a conceptual clarification of the pristine function of a utility model law before it degenerates into a petty patent law, see J. H. Reichman, Electronic Information Tools-The Outer Edge of World Intellectual Property Law, 17 U Dayton L Rev 797, 806-12 (1992).

90. See, for example, Industrial Design Protection at 476-85 (cited in note 11) (statement of Oman); Brown, $19 \mathrm{U}$ Balt L Rev at 314-20 (cited in note 85); Reichman, 22 Vand J Transnatl L at 831-36 (cited in note 16) (discussing limits of Art. XX(d) of the General Agreement on Tariffs and Trade). 
similar fate. ${ }^{91}$ For example, why not protect unpatentable biogenetically altered organisms under a parallel sui generis regime? And why tolerate exorbitant protection of industrial literature (that is, computer programs) in copyright law, only to confine industrial art and functional designs generally to a sui generis regime?92

The long-term answer to these questions is that the world's intellectual property system needs a law to protect applied know-how far more than it needs another batch of sui generis design laws. ${ }^{93}$ In this respect, any design protection law, even if limited to appearance designs, represents merely one of numerous legal metaphors that legislators have used to provide indirect protection of unpatented, noncopyrightable know-how under a classical intellectual property system dominated by the patent and copyright paradigms. This topic, introduced in my recent studies, is more fully explored in a work-in-progress entitled Legal Hybrids Between the Patent and Copyright Paradigms. ${ }^{94}$

Direct protection of applied know-how would require, however, a higher degree of consensus concerning legal means and economic ends than currently exists, and it has nothing to do with the automobile and tractor industries' thinly disguised demand for trade protection in the spare parts market. ${ }^{95}$ Routine protection of functional designs lacking any significant creative contribution cannot be reconciled with either the theoretical and economic underpinnings of classical intellectual property law or, the conceptual underpinnings of a new paradigm devised to protect incremental innovation bearing know-how on its face. ${ }^{96}$

Before any new intellectual property model can reach the drawing boards, industry must tire of disaggregating new technologies into static components that are crammed into existing legal models ${ }^{97}$ and must wholeheartedly investigate proposals to protect the dynamic aspects of present-day innovation under a unified, sui generis approach. Meanwhile, it seems unwise to throw more ad hoc legal solutions at a moving target, and it would be economic folly to enact an overly broad functional design right that saddled virtually every product on the market with some legal restraint on trade.

The validity of the pending design bills in their present form thus remains open to question even by those, like myself, who remain staunch supporters in

91. See Ralph S. Brown, Eligibility for Copyright Protection: A Search for Principled Standards, 70 Minn L Rev 579, 580-89, 606-09 (1985).

92. See Reichman, 19 U Balt $L$ Rev at 136-53 (cited in note 10) (discussing relation between problems of design protection and those of new technologies in general).

93. See Reichman, 42 Vand L Rev at 652-67, 714-16 (cited in note 14); William Kingston, The

"Thesis" Chapters," in Direct Protection of Innovation 35-86 (Kluwer, 1987).

94. See note 78.

95. See, for example, Kenneth Enborg, Industrial Design Protection in the Automobile Industry, $19 \mathrm{U}$ Balt L Rev 227 (1989/1990); James F. Fitzpatrick, Industrial Design Protection and Competition in Automobile Replacement Parts-Back to Monopoly Profits?, 19 U Balt L Rev 233 (1989/1990); William Thompson, Product Protection Under Current and Proposed Design Laws, 19 U Balt L Rev 271 (1989/1990).

96. See notes 72-75, 86-90 and accompanying text.

97. See further J. H. Reichman, Proprietary Rights in the New Landscape of Intellectual Property Law: An Anglo-American Perspective, Colum-VLA J L \& Arts (forthcoming 1992). 
principle of sui generis protection for innovative appearance designs. A tolerable sui generis solution should protect commercial designs insofar as they enhance sales appeal by virtue of "an ensemble of lines, surfaces, volumes, and profiles connected with each other in subtle or unique ways so as to give a characteristic external appearance to an article." 98 But protection should not extend beyond the creatively fashioned "look" or image that the designer conveys through features not prompted by purely functional demands of the article in question.

In this regard, I trust that Congress will resist the temptation to enact disguised barriers to trade in the form of intellectual property law. And I pray that this premature digression into the realm of functional designs will not ultimately derail efforts to enact the kind of sui generis reform that might truly help our design industries to expand their share of a discriminating world market.

98. Ladas, 2 Patents, Trademarks, and Related Rights at 829 (cited in note 88). 